\title{
Strengthening Ecological Citizenship Through Social Studies Based on the Values of Multicultural Society
}

\author{
Triani Widyanti ${ }^{1 *}$ Tetep $^{1}$
}

\begin{abstract}
${ }^{1}$ Faculty of Social Sciences Language and Literature, Indonesian Institute of Education, West Java, Indonesia
${ }^{*}$ Corresponding author.Email: trianiw@institutpendidikan.ac.id
\end{abstract}

\begin{abstract}
This study aims to examine efforts to strengthen ecological citizenship through social studies learning based on a multicultural society's values. This study used a descriptive qualitative method, which was carried out on the IPS IPI Garut Study Program students as the research subject and the Garut Regency environmental care program as the object of its study. This paper reflects a growing social issue, namely the problem of the emergence of apathy or public indifference to various environmental development activities. Education is one of the strategic sectors, which is expected to make a real contribution and defend the Indonesian national identity. Social science, in this case, IPS, views that social problems in the 21 st century do not only rest on the economic development sector or matters of a physical nature but also the development of the identity of the Indonesian nation as a pluralistic nation. Implementing social studies education in the 21 st century is needed in a classroom context and only teaches theories and applied in social life. The results showed that one of the learning applications of social studies implemented in community activities is participation in environmental activities or what is known as ecological citizenship. But also in the development of the Indonesian nation's identity as a pluralistic nation. Implementing social studies education in the 21 st century is needed in a classroom context and only teaches theories and applied in social life. The results showed that one of the learning applications of social studies implemented in community activities is participation in environmental activities or what is known as ecological citizenship. But also on the development of the Indonesian nation's identity as a pluralistic nation. Implementing social studies education in the 21 st century is needed in a classroom context and only teaches theories and applied in social life. The results showed that one of the learning applications of social studies implemented in community activities is participation in environmental activities or what is known as ecological citizenship.
\end{abstract}

Keywords: Ecological citizenship, $21^{\text {st }}$ century social studies learning, multicultural society.

\section{INTRODUCTION}

As an independent nation, Indonesia has confirmed its existence as a pluralistic nation consisting of islands, ethnicities, races, and religions scattered in various parts of Indonesia. Indonesia must have more power to deal with problems that may arise from differences because this is a logical consequence for the Indonesian state's plurality, which is prone to conflicts of interest because of these differences. Various efforts can maintain the nation's integrity, one of which is by cultivating the values of caring for fellow members of the community through various environmental-based social activities, one of the areas of life that require public concern in the field of environmental management (ecology). Indonesian social holiness is one of the elements that characterize the real Indonesian people. Concern among community members based on the spirit of cooperation is one form of social righteousness in society. The field of saving the environment is one of the critical agendas that every community can carry out. In Indonesia, many policy programs have been carried out to save the environment through development policies starting at the regional level up to the national level.

Strengthening community participation or involvement in saving the environment (ecology) can be done with the right educational approach. One can be done by implementing social studies education at the school level and education at a higher level. Social studies education should not only be limited to the classroom context with theoretical reviews. Still, it should also be continued at the practical level by mentoring and strengthening the community's capacity to put the theory into practice. Because to create a participatory society in ecology (ecological citizenship) cannot be separated from the participation of all parties. Local government is one of the government elements that has the authority to develop the community's capacity in the environmental sector. Besides that, the role of education is also huge in fostering public awareness about the environment.

The local government of Garut Regency, in this case, has carried out various program activities to save the environment. The direction of the Garut Regency 
government policy has encouraged efforts to save the environment, which needs to be supported by all parties so that it is carried out correctly and as expected. One of the programs for saving the environment in Garut Regency is by launching a mutual aid movement to clean garbage. This cooperation is carried out from the neighborhood level to public places in Garut, including working together to clean up rubbish in rivers. This activity program was also carried out by the Social Studies Education Study Program students of the Indonesian Institute of Education.

Based on the explanation above, this research will convey the importance of community involvement in environmental saving programs (ecological citizenship), especially in responding to social issues related to citizens' concern for the environment, which is increasingly concerning.

\section{REVIEW OF THEORY}

\subsection{Ecological Citizenship}

Residents have long felt the issue of environmental damage in the Garut Regency. Several environment-based communities have emerged to oversee essential government policies, especially the environmental agency, in saving the environment. Several cases related to the environment show that people must know to manage, protecting, and preserving the environment, known as ecological citizenship. Dobson [1] considers ecological citizenship to be more intellectually attractive than environmental citizenship from citizenship. Ecological citizenship determined by efforts to broaden social welfare discourse to recognize universal principles related to environmental rights and include them centrally in law, culture, and politics [1]. Smith \& Pangsapa [2] explain that ecological citizenship is part of a new generation of citizenship types that seriously take political obligations. The new generation makes ecological citizenship part of the type of citizenship. Curtin [3] says that being an ecological citizen requires a transformation in moral identity. Takahashi et al [4] say that ecological citizenship is involved in political activities that aim to support environmental causes.

Escrihuela's research [5] explains that the state and green state's role in changing citizenship in the perspective of civil society should be introduced about the promotion of ecological citizenship, which involves the creation of a just in a sustainable society. Ecological citizenship is tied to the country's territory and is practiced exclusively in environmental education in society. Ecological citizenship can be done by exemplifying one of the many models of environmental education with community involvement.

\subsection{Multicultural Society}

Furnivall [6] states that a pluralistic society is a society consisting of two or more elements that live independently, without mixing in one political unit. Clifford Geertz [7] states that a plural society is a society that is divided into subsystems that are more or less primordial bonds bound standing and each subsystem. Nasikun [8] states that a society is plural in nature insofar as that society structurally has diverse subcultures which are marked by the underdevelopment of a value system that is agreed upon by all members of society and also the value system of social units, as well as frequent social conflicts.

\section{$2.321^{\text {st }}$ Century Social Studies Education}

Banks [9] states that social studies were taught in the 21st century to prepare students to participate effectively in postindustrial societies. According to him, post-industrial society has global characteristics, such as the global economy, efforts to solve global problems, lifestyle changes, values, culture, and political sentiment. The skills in social studies education are expressed by Sapriya [10] "the skills needed in the social studies education dimension include research skills, social participation skills, thinking skills, communication skills." In essence, the application of value education in social studies learning aims to assist students in developing democratic values in people's lives.

\section{METHOD}

Research data collection tools use observation, interviews, documentation, and triangulation - the primary data source in this study as participants. The snowball sampling technique is used to increase the number of participants, which is a technique to increase participants' numbers by asking participants who have been interviewed or other related parties to recommend [11]. According to Sugiyono [12], Snowball sampling is a technique of determining the sample, which is initially small in number, then enlarges. Like a rolling snowball that gradually grows big. Following the form of qualitative research and the types of data sources used, the data collection instruments used in this study include interviews, observations, and document analysis.

Meanwhile, secondary data sources were obtained by supporting data relevant to the research context. Information obtained by researchers comes from information about the problems to be studied. Sources of data in this study can be complicated, meaning that they can be obtained from several sources, both humans and the phenomenon itself that occurs in Sukoharjo Regency. In general, HB Sutopo [13] states that "the source of data in qualitative research can be people, events or activities, places or locations, objects, various images, or recordings, documents or archives." Sources of data in this study can be complicated, meaning that they can be obtained from several sources, both human and the phenomenon itself that occurs in Sukoharjo Regency. In general, HB Sutopo [13] states that "the source of data in qualitative research can be people, events or activities, places or locations, objects, various images, or recordings, documents or archives." Sources of data in this study can be complicated, meaning that they can be obtained from several sources, both human and the phenomenon itself that occurs in Sukoharjo Regency. In general, HB Sutopo [13] states that "the source of data in qualitative research can be people, events or activities, places or locations, objects, various images, or recordings, documents or archives." 


\section{RESULTS AND DISCUSSION}

Citizen participation in preserving the environment is an essential element because citizens are part of the environment itself. The impact of environmental pollution that occurs today is an exciting thing to study, especially the assessment by looking at the participation of citizens who are part of the issue. Changes in human perspective and behavior cannot be separated from the formation of citizens' ethics and morality.

Garut Regency Government has various policies regarding saving the environment. The flash flood incident in the Cimanuk river area several years ago has become a valuable lesson for all Garut community members, primarily to protect the environment. The problem of silting rivers and disposing of waste or garbage into rivers is a significant issue in environmental improvement. The activity of Gotong Royong cleaning up waste is one example of the Garut government program to create public awareness of cleanliness and environmental sustainability that; this program is also expected to be able to increase community piety and care among fellow community members, given that cooperation is a hallmark of the Indonesian nation, which needs to be maintained.

The government's efforts certainly need support from all parties. The educational environment, including the campus environment as part of the formal education program in Indonesia, has a responsibility in shaping the nation's character and civilization, one of which is the potential for students to be part of citizens who actively participate in protecting the natural environment and around. Learning activities or lectures in the form of policies and up to the implementation stage should form young citizens who have a civilized character, marked by a fair attitude towards the environment and others to support the formation of quality citizens. The global problem of education in the $21 \mathrm{st}$ century has changed the world quickly and has become a world problem [14].

Social studies education has an essential role in raising awareness about environmental sustainability for the younger generation. At the tertiary level, social studies education is required not only to be a purely theoretical study but also to be a study that students can implement directly. Discussions about the environment are part of the social studies learning process that must be carried out by students of the IPI Garut IPS study program. They must convey their ideas and ideas related to attitudes and practices associated with social science significant theories. The application of these ideas and ideas is then applied directly through various cooperation activities tailored to the Garut Regency government program.

The cooperation action to clean up rubbish in the campus environment and each residence's neighborhood involves all IPS study program students and lasts for two days. Through this activity, IPS students can also invite and educate the community around the campus, both children, adolescents, and adults, to participate and be active in maintaining a clean environment. Education is carried out by providing explanations regarding the sorting of organic and inorganic waste, educating the public about using recyclable waste and processing waste that can be used for fertilizer purposes for plants, and providing directions and recommendations for reducing household waste. These activities are based on the 3R program (Reduce, Reuse, Recycle)

The community's enthusiasm to be involved in this cooperation activity is quite good. It can be seen from the large number of community members who participated in helping both energy and material. The application of the social studies learning process that is carried out like this is more accessible to many groups than learning, which only prioritizes the study of significant theories in class without direct implementation in the community. 21st Century social studies learning should use various strategies so that it is far from saturated. The goal of making people or citizens aware of environmental sustainability can be realized.

\section{CONCLUSION}

Social studies education has an essential role in fostering the values of ecological citizenship for all social levels. By implementing cooperation activities to clean up garbage by IPI Garut IPS study program students, the community can be educated and be involved in efforts to conserve and save the environment. Based on the activities of implementing social studies learning in the cooperation program, it is concluded that:

1. Students of the Social Studies Study Program have been able to apply the results of learning studies in the realm of theory to practice. Theory development related to ecological citizenship is implemented in cooperation activities to clean garbage in the campus environment by inviting other community members.

2. With these cooperation activities, the public can be educated about the importance of environmental conservation and sorting and treating waste beneficial to human life.

3. Meaningful social studies learning is when the ideas in significant theories can be applied in people's lives so that all citizens can felt their benefits.

\section{REFERENCES}

[1] A. Dobson, Citizenship and the Environment. Oxford: Oxford University Press, 2003.

[2] M. J. Smith and O. Pangsapa, Environment and citizenship Integrating justice, responsibility and civic engagement. Zed Books: London, 2008.

[3] D. Curtin, "Ecological Citizenship," in Handbook of Citizenship Studies, E. F. Isin and B. S. Turner, Eds. New Delhi: Sage Publications, 2002.

[4] Y. Takahashi et al., "Novel genetic resources in the genus vigna unveiled from gene bank accessions," PLoS One, vol. 11, no. 1, 2016, doi: 10.1371/journal.pone.0147568.

[5] C. Melo-Escrihuela, "Promoting ecological citizenship: Rights, duties and political agency," Acme, vol. 7, no. 2, pp. 113-134, 2008. 
[6] J. Furnivall, Colonial Policy and Practice: $A$ comprative study of Burma and the Netherlands India. New York: New York University Press, 1948.

[7] B. Rajab, Pluralitas Masyarakat Indonesia Suatu Tinjauan Umum. Jakarta: LP3ES, 1996.

[8] Nasikun, Sistem Sosial Indonesia. Jakarta: Rajawali Press, 1996.

[9] J. A. Banks, Teaching strategies for the Social Studies: Inquiring, Valuing and decision-making. New York: Longman, 1990.

[10] Sapriya, Pendidikan IPS: Konsep dan Pembelajaran. Bandung: Remaja Rosdakarya, 2011.

[11] J. W. Creswell, Qualitative Inquary and Research Design: Choosing Among Five Tradition. London, New Delhi: Sage Publications, 1998.

[12] Sugiyono, Metode Penelitian Kuantitatif, Kualitatif \& RND. Bandung: Alfabeta, 2010.

[13] Sutopo, Metodologi Penelitian. Surakarta: UNS Press, 2002.

[14] S. Pertiwi and S. Samsuri, "Pembentukan kompetensi ekologis dengan model pembelajaran kontekstual dan berbasis masalah dalam PPKn di SMP," J. Civ. Media Kaji. Kewarganegaraan, vol. 14, no. 2, pp. 154-165, 2017, doi: 10.21831/civics.v14i2.14972. 